\section{Correspondence}

https://doi.org/10.11646/zootaxa.5060.4.8

http://zoobank.org/urn:lsid:zoobank.org:pub:8565F347-8BFF-4347-A867-3FA7F941206E

\title{
A field guide to distinguishing Octopus insularis and Octopus americanus (Octopoda: Octopodidae)
}

\author{
CAITLIN E. O’BRIEN ${ }^{1}$, CHELSEA O. BENNICE ${ }^{2} \&$ TATIANA LEITE ${ }^{3}$ \\ ${ }^{1}$ Center for Marine Resource Studies, The School for Field Studies, 1, Cockburn Harbour TKCA 1ZZ, Turks \& Caicos Islands. \\ "="cobrien@fieldstudies.org; (1) https://orcid.org/0000-0003-3557-1332 \\ ${ }_{2}^{2}$ Department of Biological Sciences, Florida Atlantic University, Boca Raton, Florida, USA. \\ =" cbennice@fau.edu; $\odot$ https://orcid.org/0000-0002-1899-1303 \\ ${ }^{3}$ Department of Ecology and Zoology, Universidade Federal de Santa Catarina, Floriaópolis/SC Brazil. \\ "'tatiana.leite@ufsc.br; ‘ https://orcid.org/000-0001-9117-9648
}

Shallow-water, benthic octopuses from the Caribbean, Gulf of Mexico and tropical western Atlantic have undergone extensive taxonomic expansion and revision over the last two decades (reviewed in Avendaño et al. 2020a). Many of the geographically-overlapping octopuses within this region were cryptic (sensu Bickford et al. 2007), with only subtle differences in habitats, morphology and body patterns that can make it difficult to distinguish between species, especially in the field (Avendaño et al. 2020a; Lima et al. 2020b). Moreover, considerable variation in morphology, behavior and body patterning exists within species (Leite et al. 2008; Amor et al. 2016; Avendaño et al. 2020a). The coexistence of species that appear similar and exhibit intra-species variation has resulted in a great deal of confusion as to the identity and habits of octopuses in these regions (Lima et al. 2017). Recent taxonomic and molecular studies have been instrumental in resolving this confusion (Amor et al. 2016) and represent critical early steps in elucidating the evolutionary course of the genus Octopus.

Previously, any large, non-ocellated octopus in the Caribbean, Gulf of Mexico or western Atlantic observed primarily during the day was referred to as Octopus vulgaris Cuvier, or as a member of the O. vulgaris complex (e.g., Norman 2003). However, $O$. vulgaris is now recognized as a cosmopolitan species group comprising at least six subtropical, tropical and temperate species $(O$. vulgaris sensu stricto, $O$. vulgaris Type III, $O$. sinensis, $O$. tetricus, $O$. cf. tetricus, and O. americanus; Amor et al. 2016, 2017, 2019; Avendaño et al. 2020a). In 2008, O. insularis Leite \& Haimovici was named and described based on specimens from Brazil (Leite et al. 2008) and later shown to be morphologically distinct and genetically distant from the O. vulgaris species complex (Ritschard et al. 2019; Lima et al. 2020b). Over a decade later, a study reported $O$. vulgaris Type II (Amor et al. 2016) from Brazil and O. vulgaris Type I from Mexico and North America as a cryptic species within the $O$. vulgaris complex and suggested reinstating the name $O$. americanus Monfort (Avendano et al 2020). Octopus insularis and O. americanus look very similar, overlap geographically throughout much of Caribbean, Gulf of Mexico and the western Atlantic (Figure 1) and as a result are commonly mistaken for one another. Moreover, despite the re-designation of these two species as separate from $O$. vulgaris, this name is still often incorrectly applied to both $O$. insularis and $O$. americanus in the western Atlantic.

Accurate species identification and description is important for assessing population dynamics as well as for promoting conservation and sustainable fisheries (Lima et al. 2017). Both O. insularis and O. americanus are targeted in artisanal and commercial fisheries throughout their range (e.g., Sauer et al. 2020) and have been the focus of recent and on-going research in behavioral ecology and the effects of climate change (e.g., Ángeles-González et al. 2020; Lima et al. 2020a; Medeiros et al. 2020; Rosas-Luis et al. 2019). To facilitate further research with these two species, particularly fieldwork (e.g., abundance estimates, in situ behavioral assays), accurate field guides for species identification are needed. To this end, we describe three differences (two visual and one contextual) that can facilitate the identification of $O$. insularis and $O$. americanus in the field or from photographs and videos, eliminating the need to handle or sacrifice animals for species identification. These body pattern components and habitat features have been validated and utilized successfully for species differentiation in locations where the presence of both species was established genetically, including Brazil (Lima et al. 2017) and Mexico (González-Gómez et al. 2018). Unfortunately, these distinguishing characteristics are not widely known, and we highlight them here. 


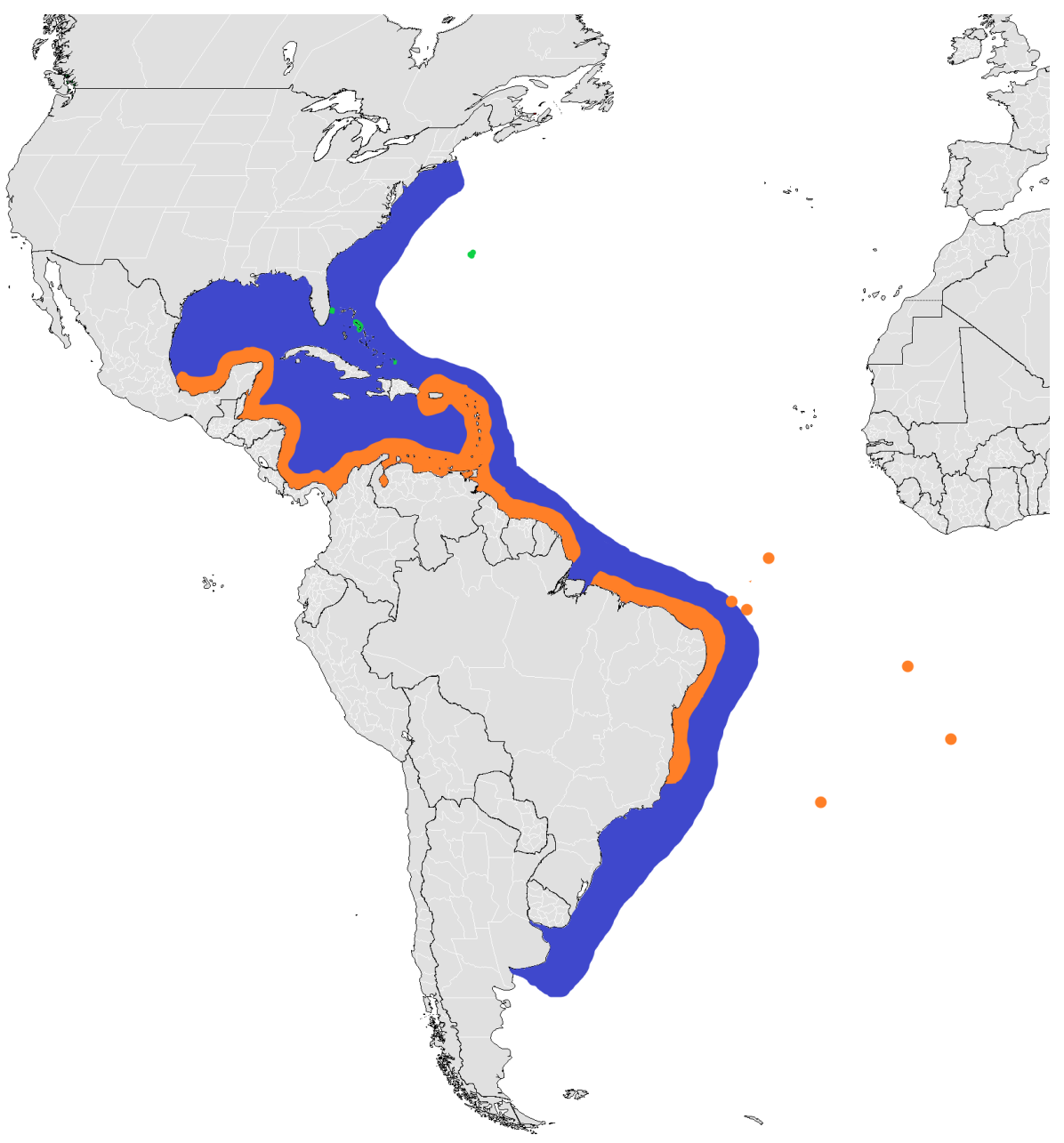

FIGURE 1. The geographic ranges of Octopus insularis and O. americanus. The currently-recognized range of $O$. americanus is indicated in blue (from Avendano et al. 2020a), the currently-recognized range of $O$. insularis in orange (from Lima et al. 2017) and the proposed range extensions for $O$. insularis are indicated in green (this publication).

\section{Differences in body pattern components}

The most notable visual distinction between the two species is a difference in the ventral surface of the arms. Octopus insularis has a distinct configuration of dark purple/red/brown "patches" against a light background (Figure 2a). Leite \& Mather (2008) named this component "red/white reticulate on ventral arms," and found it to be a species-specific feature present in every specimen examined. The contrast between the dark patches and light background can vary in intensity both over time in a single individual and across individuals (CEO, pers. obs.), but is usually visible in situ and readilyapparent in photographs and videos. By contrast, the ventral surface of the arms of $O$. americanus have more uniform coloring, ranging from orange to brown, with no well-defined dark "patches" or reticulation (Figure 2b; Avendaño et al. 2020a). This distinguishing characteristic has the advantage of being easy to discern, even if the octopus is inside its den.

A second difference between the two species is located in the area around the eye during each species' deimatic (sometimes called dymantic) display. This body pattern is evoked in octopuses and other cephalopods when they are startled or threatened, and consists of a paling of the mantle and arms and a darkening of the head around the eyes to varying degrees (Packard \& Sanders 1971). In O. insularis, the deimatic display is comprised in part by a white eye and a encircling pale ring (appearing white or blue-green), often accompanied by a dark eye bar, within a broader, darkened area (Figure 3a; Leite \& Mather 2008). By contrast, the deimatic display of O. americanus consists of a continuous darkening around the eyes - the eyes themselves are dark, as is the entire surrounding area (Figure 3b). While the deimatic body pattern is transient, it is often evoked both inside and outside the den by the approach of a diver or photographer, and thus commonly observed. 


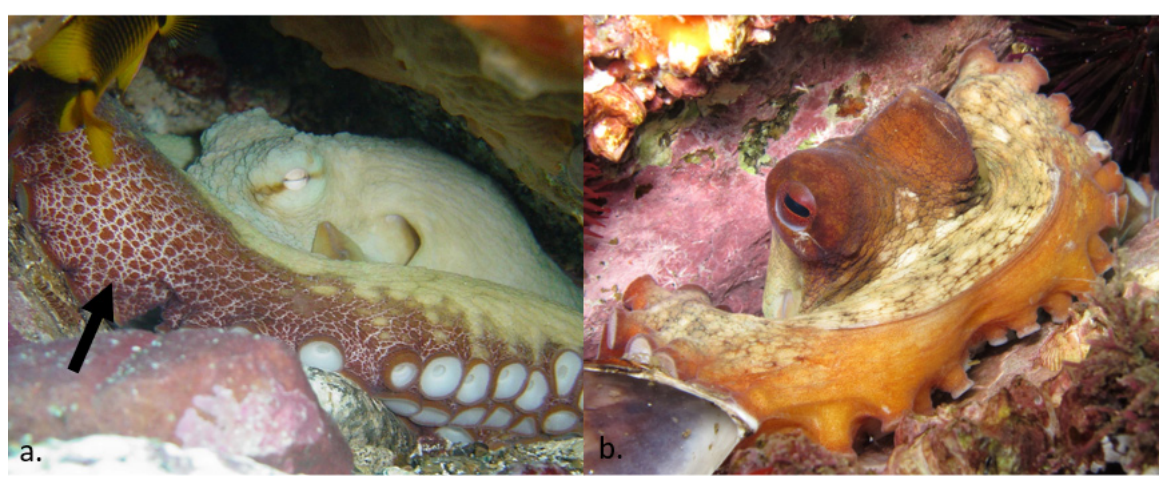

FIGURE 2. a.) Octopus insularis from Brazil (photo by Diogo Pagnoncelli/Projeto Cephalopoda). Arrow indicates the pattern of dark "patches" against the light background on the ventral arms that can be used to distinguish the species from b.) Octopus americanus from Brazil (photo by Fernando Moraes) with a uniform pattern on the ventral surface of the arms.

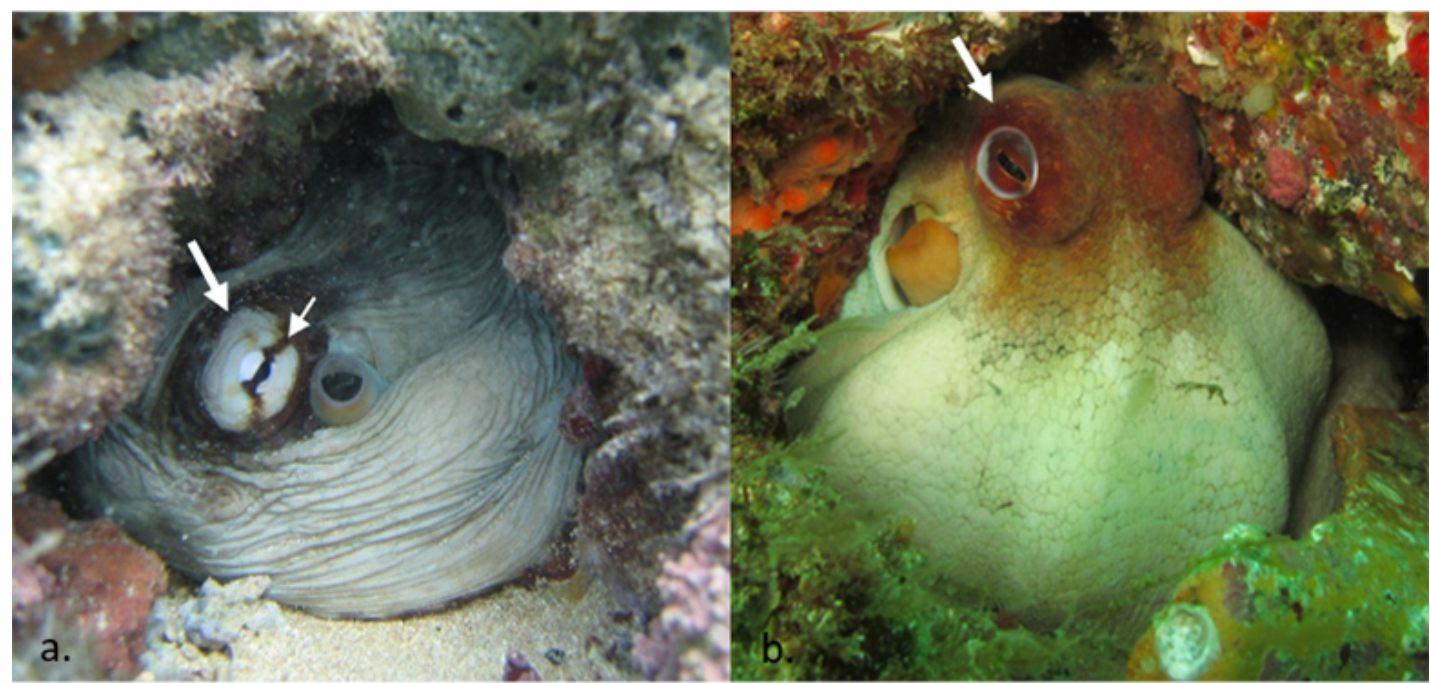

FIGURE 3. The deimatic display of a.) O. insularis includes a white eye, a light ring around the eye and often a distinct, dark eye bar within the darkened area (photo by TL, Brazil), while in the deimatic display of b.) O. americanus, the entire area around the eyes is darkened (photo by Fernando Moraes, Brazil).

We examined photographs and videos of 29 individual octopuses (15 O. insularis and 14 O. americanus) from genetically-identified populations in the Brazilian octopus fishery, where both species are common and co-occur in the same areas. These photographs and videos were taken in the specific conditions (temperature and depth) that each species is known to inhabit (see next section). The $O$. insularis and $O$. americanus individuals could be identified as such using one or both of the visual characteristics mentioned above: $55 \%$ individuals could be identified by the ventral arm surfaces alone, $14 \%$ by the deimatic display alone and $31 \%$ could be identified by both features. Specifically, dark patches on the ventral arm surface and a light ring around the eye during the deimatic display were never observed in O. americanus. Thus, these two features are both ubiquitous and species-specific, making them ideal visual indicators.

\section{Differences in habitat}

Habitat parameters that can be used in combination with each other to distinguish O. insularis from O. americanus (based on where an animal is encountered) are water temperature, depth and substrate type. Octopus insularis is reported as a tropical species with adults and juveniles inhabiting waters between 23 and $30^{\circ} \mathrm{C}$ (Leite et al. 2008) and paralarvae in water temperatures ranging between 24 and $29^{\circ} \mathrm{C}$ (Ángeles-González et al. 2020). By contrast, O. americanus is reported as a mainly subtropical and temperate species, with adults inhabiting waters between 18 and $25^{\circ} \mathrm{C}$ (Amado et al. 2015; Bastos 2018) and paralarvae in waters between 19 and $24^{\circ} \mathrm{C}$ (Ángeles-González et al. 2020).

Where the two species overlap in geographic range, juvenile and adult $O$. insularis tend to be found on shallower $(0.5-40 \mathrm{~m})$ reef and rocky substrates in warmer water (Leite et al. 2009; Rosas-Luis et al. 2019), while juvenile and adult 
O. americanus are found up to $200 \mathrm{~m}$ in cooler waters on rock, rubble, shell beds or on the interface between rock and sand (Lima et al. 2017; Avendaño et al. 2020b). In subtropical regions, where shallow areas are typically less than $24^{\circ} \mathrm{C}$ throughout the year, $O$. insularis is less common, although its range may shift due to climate change (Ángeles-González et al. 2020; Lima et al. 2020a).The disparate habitat preferences of $O$. insularis and $O$. americanus likely allow the two species to partition the range in which they co-occur by temperature, substrate type and depth (Amado et al. 2015; Amor et al. 2016). It also explains why previously, the "Caribbean O. vulgaris" (Norman 2003) - really the conflated and misidentified $O$. insularis and $O$. americanus - was reported as having a geographic range that spanned tropical, subtropical and temperate waters.

\section{Octopus insularis: New sightings and proposed geographic range expansion}

The geographic range of $O$. insularis is currently recognized as extending from the coast of southern Brazil to as far north as Puerto Rico in the Caribbean to the east, and the Yucatan Peninsula in the Gulf of Mexico to the west (Avendaño et al. 2020a; Figure 1). However, we have collected photographs of 25 individual octopuses displaying the species-specific characteristics described above for $O$. insularis from locations farther north than this recognized range, including the Turks and Caicos Islands (11 individuals), south Florida (five individuals), the Bahamas (six individuals) and Bermuda (three individuals; Table 1, Figures 1 and 4). Because these individuals possess the characteristics described above for $O$. insularis, we recommend tentatively extending the recognized range of this species to include these areas until a formal genetic analysis can be conducted.

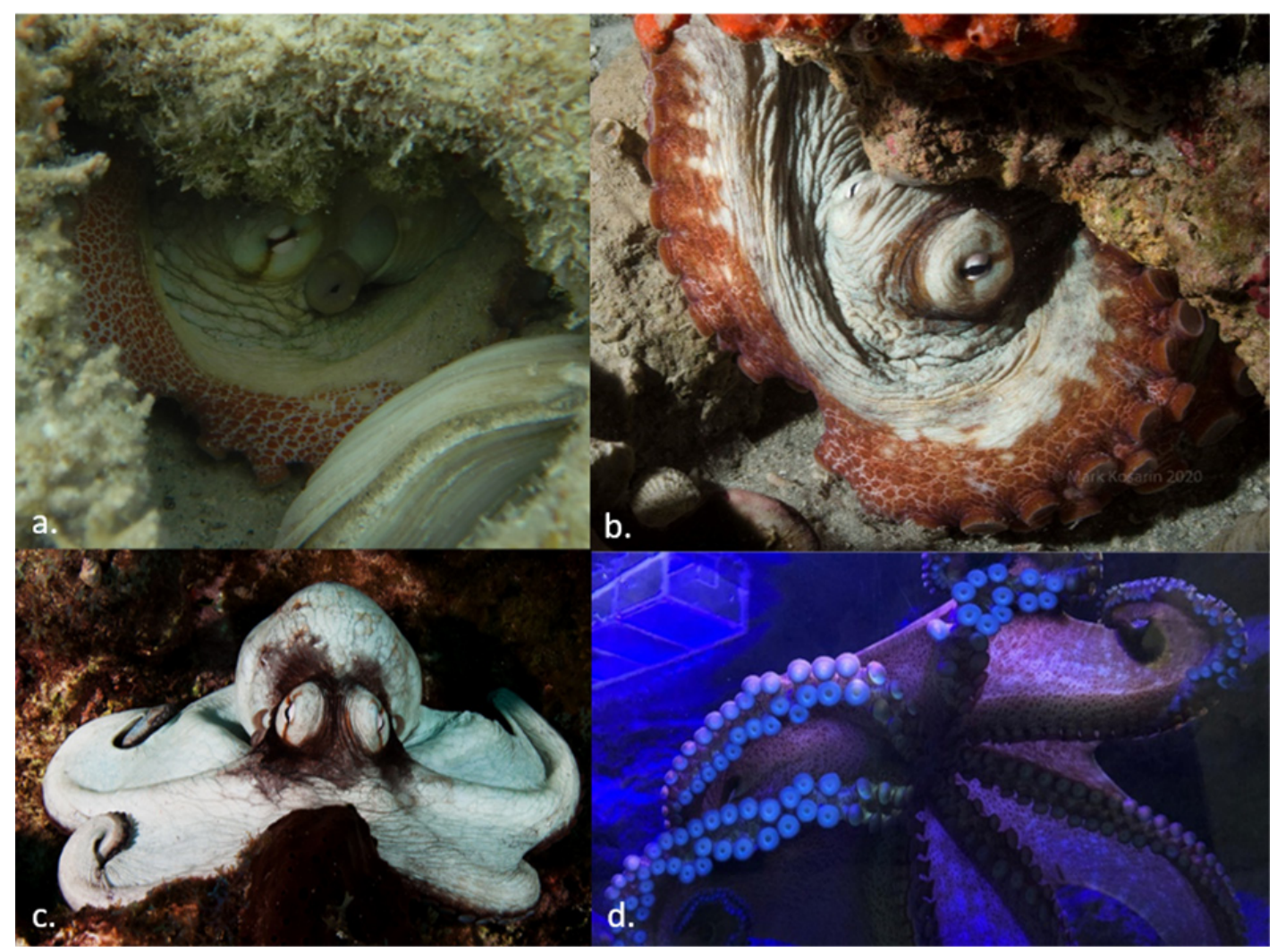

FIGURE 4. Representative photographs of $O$. insularis from regions north of its currently-recognized range. a.) In the Turks and Caicos Islands, showing dark patches on the ventral arms taken in $<2 \mathrm{~m}$ of water at approximately $27^{\circ} \mathrm{C}$ (photo by CEO). b.) In south Florida, showing the dark patches on the ventral arms and deimatic display with the light ring around the eye and dark eye bar taken in $24 \mathrm{~m}$ of water at $29^{\circ} \mathrm{C}$ (photo by Mark Kosarin) c.) In the Bahamas, showing a deimatic display with the light ring around the eye and dark eye bar taken in $8 \mathrm{~m}$ of water at approximately $28^{\circ} \mathrm{C}$ (photo by Shane Gross). d.) In Bermuda, showing darks patches on ventral arms and captured in $1 \mathrm{~m}$ of water (photo by Nesta Wellman at the Bermuda Aquarium, Museum and Zoo). 
TABLE 1. Individual $O$. insularis $(\mathrm{n}=25)$ documented by photograph and/or video in four locations north of the species' currently-recognized range. The column "Ventral arms only" refers to the number of individuals identified solely by the presence of dark patches on the ventral arms; "Deimatic display only" refers to individuals identified solely by the presence of a light ring around the eye when the deimatic pattern is displayed; "Both" refers to individuals in which both features (ventral arms and deimatic light eye ring) could be discerned.

\begin{tabular}{ccccc}
\hline & Ventral arms only & Deimatic display only & Both & Total \# individuals photographed \\
\hline Bermuda & 3 & 0 & 0 & 3 \\
Bahamas & 4 & 1 & 1 & 6 \\
South Florida & 4 & 0 & 1 & 5 \\
Turks and Caicos & 7 & 3 & 1 & 11 \\
\hline
\end{tabular}

\section{Conclusion}

The visual and contextual differences between $O$. insularis and $O$. americanus described and illustrated here with sideby-side photographs should enable researchers, divers, marine photographers and citizen scientists working in the field to easily distinguish between the species without the need for a tissue sample or close visual inspection. This should avert confusion in future literature, enable more accurate assessments of the two species' respective habits and ecology and facilitate the study of any geographic range shifts that occur as the result of climate change (see Ángeles-González et al. 2020; Lima et al. 2020a). We have summarized these differences as well as the recognized and hypothesized geographic range of each species in a printable field identification guide available as Supplemental Material.

\section{Acknowledgments}

The results presented here are based on photographs and videos of octopuses taken in situ, and in one instance, at an aquarium. Permissions have been obtained for the publication of all photographs. We are grateful for the support and assistance of the School for Field Studies Center for Marine Resources, Dr. Jennifer Mather, Dr. Lisa Ray and the Bermuda Aquarium, Museum and Zoo. We also thank Mark Kosarin, Shane Gross, Bryant Turffs, Jessica Pate, Diogo Pagnoncelli and Fernando Moraes for contributing photos and videos. We are also grateful to the Chico Mendes Institute for Biodiversity Conservation (MMA/ICMBIO) and the Brazilian Navy for logistical support and the Coordination for the Improvement of Higher Education Personnel (CAPES/Projeto Ciencias do Mar II - 23038.004807/2014-01) for financial support. We thank Alessandra Pak for assistance with the field guide, and Michael D. Amor and Roberto Gonzalez Gomez for their insightful suggestions for improving this short communication.

\section{References}

Amado, E.M., Souza-Bastos, L.R., Vidal, E.A.G., Leite, T.S. \& Freire, C.A. (2015) Different abilities to regulate tissue hydration upon osmotic challenge in vitro, in the cephalopods Octopus vulgaris and O. insularis. Marine and Freshwater Behaviour and Physiology, 48, 205-211. https://doi.org/10.1080/10236244.2015.1024078

Amor, M.D., Laptikhovsky, V., Norman, M.D. \& Strugnell, J.M. (2017) Genetic evidence extends the known distribution of Octopus insularis to the mid-Atlantic islands Ascension and St Helena. Journal of the Marine Biological Association of the United Kingdom, 97, 753-758. https://doi.org/10.1017/S0025315415000958

Amor, M.D., Doyle, S.R., Norman, M.D., Roura, A., Hall, N.E., Robinson, A.J., Leite, T.S. \& Strugnell, J.M. (2019) Genome-wide sequencing uncovers cryptic diversity and mito-nuclear discordance in the Octopus vulgaris species complex. BioRxiv, 573493. https://doi.org/10.1101/573493

Amor, M.D., Norman, M.D., Roura, A., Leite, T.S., Gleadall, I.G., Reid, A., Perales-Raya, C., Lu, C.-C., Silvey, C.J. \& Vidal, E.A. (2016) Morphological assessment of the Octopus vulgaris species complex evaluated in light of molecular-based phylogenetic inferences. Zoologica Scripta, 46, 275-288. https://doi.org/10.1111/zsc.12207

Ángeles-González, L.E., Lima, F.D., Caamal-Monsreal, C., Díaz, F. \& Rosas, C. (2020) Exploring the effects of warming seas by using the optimal and pejus temperatures of the embryo of three Octopoda species in the Gulf of Mexico. Journal of Thermal Biology, 94, 1-11. https://doi.org/10.1016/j.jtherbio.2020.102753

Avendaño, O., Roura, Á., Cedillo-Robles, C.E., González, Á.F., Rodríguez-Canul, R., Velázquez-Abunader, I. \& Guerra, Á. 
(2020a) Octopus americanus: A cryptic species of the $O$. vulgaris species complex redescribed from the Caribbean. Aquatic Ecology, 54, 909-925.

https://doi.org/10.1007/s10452-020-09778-6

Avendaño, O., Hernández-Flores, A., Velázquez-Abunader, I., Fernández-Jardón, C., Cuevas-Jimenez, A. \& Guerra, Á. (2020b) Potential biomass and distribution of octopus in the eastern part of the Campeche Bank (Yucatán, Mexico). Scientia Marina, 84 (2), 1-10. https://doi.org/10.3989/scimar.05007.01A

Bastos, P. (2018) Fisiologia digestiva e dieta peletizada para engorda do polvo Octopus vulgaris tipo II. Universidade Federal de Santa Catarina. Available from: https://repositorio.ufsc.br/handle/123456789/193116 (accessed 4 October 2021)

Bickford, D., Lohman, D.J., Sodhi, N.S., Ng, P.K., Meier, R., Winker, K., Ingram, K.K. \& Das, I. (2007) Cryptic species as a window on diversity and conservation. Trends in Ecology \& Evolution, 22, 148-155. https://doi.org/10.1016/j.tree.2006.11.004

González-Gómez, R., de los Angeles Barriga-Sosa, I., Pliego-Cárdenas, R., Jiménez-Badillo, L., Markaida, U., Meiners-Mandujano, C. \& Morillo-Velarde, P.S. (2018) An integrative taxonomic approach reveals Octopus insularis as the dominant species in the Veracruz Reef System (southwestern Gulf of Mexico). PeerJ, 6, e6015. https://doi.org/10.7717/peerj.6015

Leite, T.S., Haimovici, M., Mather, J. \& Oliveira, J.L. (2009) Habitat, distribution, and abundance of the commercial octopus (Octopus insularis) in a tropical oceanic island, Brazil: Information for management of an artisanal fishery inside a marine protected area. Fisheries research, 98, 85-91. https://doi.org/10.1016/j.fishres.2009.04.001

Leite, T.S., Haimovici, M., Molina, W. \& Warnke, K. (2008) Morphological and genetic description of Octopus insularis, a new cryptic species in the Octopus vulgaris complex (Cephalopoda: Octopodidae) from the tropical southwestern Atlantic. Journal of Molluscan Studies, 74, 63-74. https://doi.org/10.1093/mollus/eym050

Leite, T.S. \& Mather, J.A. (2008) A new approach to octopuses' body pattern analysis: A framework for taxonomy and behavioral studies. American Malacological Bulletin, 24, 31-41. https://doi.org/10.4003/0740-2783-24.1.31

Lima, F.D., Ángeles-González, L.E., Leite, T.S. \& Lima, S.M. (2020a) Global climate changes over time shape the environmental niche distribution of Octopus insularis in the Atlantic Ocean. Marine Ecology Progress Series, 652, 111-121. https://doi.org/10.3354/meps13486

Lima, F.D., Berbel-Filho, W.M., Leite, T.S., Rosas, C. \& Lima, S.M. (2017) Occurrence of Octopus insularis Leite and Haimovici, 2008 in the Tropical Northwestern Atlantic and implications of species misidentification to octopus fisheries management. Marine Biodiversity 47, 723-734. https://doi.org/10.1007/s12526-017-0638-y

Lima, F.D., Strugnell, J.M., Leite, T.S. \& Lima, S.M. (2020b) A biogeographic framework of octopod species diversification: the role of the Isthmus of Panama. PeerJ, 8, 1-19. https://doi.org/10.7717/peerj.8691

Medeiros, S.L. de S., de Paiva, M.M.M., Lopes, P.H., Blanco, W., de Lima, F.D., de Oliveira, J.B.C., Medeiros, I.G., Sequerra, E.B., de Souza, S. \& Leite, T.S. (2020) Evidence of Sleep Cycle Analogous to Vertebrate SWS/REM Alternation in the Octopus. REM Alternation in the Octopus, 2020, 1-19. https://doi.org/10.7717/peerj.8691

Norman, M.D. (2003) Octopus vulgaris Species Complex. In: Cephalopods: A World Guide. ConchBooks, Hachenheim, pp. $262-266$.

Packard, A. \& Sanders, G.D. (1971) Body patterns of Octopus vulgaris and maturation of the response to disturbance. Animal Behaviour, 19, 780-790. https://doi.org/10.1016/S0003-3472(71)80181-1

Ritschard, E.A., Guerrero-Kommritz, J. \& Sanchez, J.A. (2019) First molecular approach to the octopus fauna from the southern Caribbean. PeerJ, 7, 1-14. https://doi.org/10.7717/peerj.7300

Rosas-Luis, R., Jiménez Badillo, M. de L., Montoliu-Elena, L. \& Morillo-Velarde, P.S. (2019) Food and feeding habits of Octopus insularis in the Veracruz Reef System National Park and confirmation of its presence in the southwest Gulf of Mexico. Marine Ecology, 40, e12535. https://doi.org/10.1111/maec.12535

Sauer, W.H., Gleadall, I.G., Downey-Breedt, N., Doubleday, Z., Gillespie, G., Haimovici, M., Ibáñez, C.M., Katugin, O.N., Leporati, S., Lipinski, M.R., Markaida, U., Ramos-Castillejos, J., Rosa, R., Villanueva, R., Arguelles, J., Briceño, F.A., Carrasco, S.A., Che, L.J., Chen, C.-S., Cisneros, R., Conners, E., Crespi-Abril, A.C., Kulik, V., Drobyazin, E.N., Emery, T., Fernández-Álvarez, F.Á., Furuya, H., González, L.W., Gough, C., Krishnan, P., Kumar, A.B., Leite, T.S., Lu, C.-C., Mohamed, K.S., Nabhitabhata, J., Kyosei, N., Petchkamnerd, J., Putra, D., Rocliffe, S., Sajikumar, K.K., Sakaguchi, H., Samuel, D., Sasikumar, G., Wada, T., Zheng, X., Tian, Y., Pang, Y. \& Yamrungrueng, A. (2020) World Octopus Fisheries. Reviews in Fisheries Science \& Aquaculture, 29 (3), 279-429.

https://doi.org/10.1080/23308249.2019.1680603 